\title{
Pengaruh Temperatur / Suhu Terhadap Tegangan Yang Dihasilkan Panel Surya Jenis Monokristalin (Studi Kasus: Baristand Industri Surabaya)
}

\author{
The Effect Of Temperature On Voltage \\ Produced By Monocrystalline Solar Panel \\ (Case Study : Baristand Industri Surabaya)
}

\author{
Deny Suryana \\ Kementerian Perindustrian \\ Baristand Industri Surabaya \\ Surabaya, Indonesia \\ denysuryana.81@gmail.com
}

\author{
M. Marhaendra Ali \\ Kementerian Perindustrian \\ Baristand Industri Surabaya \\ Surabaya, Indonesia \\ ali_industri@yahoo.com
}

\begin{abstract}
Abstrak - Indonesia sebagai negara tropis memiliki kelebihan pada sinar matahari. Salah satu pemanfaatan sinar matahari menggunakan menjadi energi listrik menggunakan Panel Surya. Panel Surya adalah sebuah elemen semikonduktor yang dapat mengkonversi energi surya menjadi energi listrik dengan prinsip fotovoltaik. Tegangan dan Arus listrik yang dihasilkan sel surya dipengaruhi oleh tingkat intensitas radiasi cahaya matahari dan suhu udara lingkungan.Semakin rendah intensitas radiasi cahaya matahari maka makin rendah pula arus dan tengangan yang dihasilkan.Temperatur lingkungan disekitar panel surya juga memiliki kontribusi dalam perubahan temperatur pada selsel surya. Akibat kenaikan temperatur, maka Tegangan listrik yang diproduksi oleh panel surya menjadi berkurang. Untuk kondisi Surabaya, terjadi pengurangan tegangan listrik sebesar $\left.0.22 \mathrm{~V} /{ }^{\circ} \mathrm{C}\right)$ jika menggunakan panel surya jenis monokristalin.
\end{abstract}

Kata kunci : matahari, panel surya, tegangan listrik

Abstract-Indonesia as a tropical country has an advantage in sunlight. One of the utilization of sunlight is turning them into electrical enegy using Solar Pane. Solar Panel is a semiconductor element that can convert solar energy into electric energy by photovoltaic principle. The electric voltage and current produced by solar cell is affected by sunlight radiation intensity level and environmental temperature. The lower the sunlight radiation intensity, the less current and voltage that will be produced. Environmental temperature around a solar panel also contributes in temperature change of solar cells. Due to rise of temperature, electric voltage that is produced by solar panel will decrease. For condition of Surabaya, there was a decrease of $-111.05 \mathrm{~V}$ when using monochrystaline.

Keyword : Sun, solar panel, electric

\section{PENDAHULUAN}

Sel surya adalah sebuah elemen semikonduktor yang dapat mengkonversi energi surya menjadi energi listrik dengan prinsip fotovoltaik. Modul surya adalah kumpulan beberapa sel surya, dan panel surya adalah kumpulan beberapa modul surya. Tegangan dan arus listrik yang dihasilkan oleh sel surya dipengaruhi oleh dua variabel fisis, yaitu intensitas radiasi cahaya matahari dan suhu lingkungan. Intensitas radiasi cahaya matahari yang diterima sel surya sebanding dengan tegangan dan arus listrik yang dihasilkan oleh sel surya, sedangkanapabila suhu lingkungan semakin tinggi dengan intensitas radiasi cahaya matahari yang tetap, maka tegangan panel surya akan berkurang dan arus listrik yang dihasilkan akan bertambah.[1] Perubahan temperatur sel-sel surya ini diakibatkan oleh temperatur, kondisi awan dan kecepatan angin di lingkungan sekitar daerah penempatan panel surya.[2],[3]. Dari penelitian sebelumnya telah dibahas perubahan kapasitas energi listrik pada panel surya untuk menghasilkan tegangan dan arus dipengaruhi temperatur suhu sekitar dan intensitas.[4]Bahkan perubahan temperatur yang sangat cepat dan ekstrim dapat menyebabkan terganggunya produksi listrik pada suatu Pembangkit Listrik Tenaga Surya[5]. Pada penelian ini bertujuan untuk mengetahui perubahan kapasitas produksi listrik panel surya akibat perubahan temperature/suhu radiasi matahari.
A. Model Tegangan Listrik Panel Surya
TerhadapTemperatur
Tegangan listrik yang dihasilkan oleh panel surya dapat didefinisikan sebagai berikut:[2]

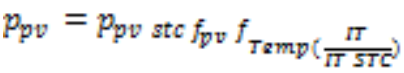


dimana $P P V, S T C$ adalah kapasitas tegangan panel surya pada kondisi uji baku $(\mathrm{kV}), f_{P V}$ adalah factor susut $(\%), I_{T}$ adalah radiasi matahari global yang mengenai permukaan panel surya $\left(\mathrm{kW} / \mathrm{m}_{2}\right)$, IT,STC radiasi matahari pada kondisi uji baku $(1 \mathrm{~kW} / \mathrm{m} 2)$, dan $f_{\text {temp }}$ adalah faktor susut akibat perubahan temperatur. Faktor susut adalah pengurangan tegangan luaran panel surya akibat debu/kotoran pada permukaan panel, rugirugi pengawatan, dampak bayangan yang menutupi panel, usia pakai, serta hal lain yang dapat menyebabkan tegangan luaran panel surya menyimpang dari kondisi ideal [5].

Faktor susut akibat perubahan temperatur dapat dihitung sebagai berikut:

$\mathrm{F}_{\text {temp }}=\left[1+\alpha_{p}\left(T_{c-} T_{c S T C}\right)\right.$

dimana $\alpha_{p}$ adalah koefisien temperatur tegangan $\left(\% /{ }^{\circ} \mathrm{C}\right), T_{c}$ adalah temperatur sel surya $\left({ }^{\circ} \mathrm{C}\right)$, dan $T_{c, S T C}$ adalah temperatur sel surya pada kondisi uji baku $\left(25^{\circ} \mathrm{C}\right)$.

Koefisien temperatur tegangan menunjukkan seberapa kuat pengaruh temperatur sel surya terhadap tegangan listrik luaran panel. Koefisien ini bernilai negatif karena tegangan luaran panel surya berkurang jika temperatur sel surya meningkat. Besarnya nilai koefisien temperature tegangan tergantung pada jenis panel surya. Nilai koefisien ini adalah nol apabila pengaruh temperatur terhadap tegangan listrik panel surya diabaikan.

Temperatur sel surya, $T_{c}$ adalah temperatur yang diukur pada permukaan panel surya. Pada malam hari, nilai temperatur sama dengan temperatur lingkungan sekitarnya, namun pada siang hari saat terik matahari, nilai temperatur dapat mencapai $34^{\circ} \mathrm{C}$ atau lebih di atas temperatur lingkungan sekitarnya pada daerah kalimantan. Untuk menghitung temperatur sel surya ini dapat menggunakan persamaan sebagai berikut: [4]

$T c=T_{Q}+I_{T}\left(\frac{T_{c} N D C T-T a, N D C T}{\pi T_{\text {NOCCT}}}\right)\left(1-\frac{\mathrm{mc}}{T a}\right)$

dimana $T a$ adalah temperatur daerah sekitar $\left({ }^{\circ} \mathrm{C}\right), T c, N O C T$ adalah temperatur nominal sel surya $\left({ }^{\circ} \mathrm{C}\right), \mathrm{Ta}, N O C T$ adalah temperatur daerah sekitar di mana temperatur nominal sel surya didefinisikan $\left(25^{\circ} \mathrm{C}\right), \quad I T, N O C T$ adalah intensitas matahari pada temperatur nominal sel surya didefinisikan, $\eta_{c}$ adalah efisiensi konversi listrik panel surya (\%), serta Ta adalah tingkat penyerapan panel surya. Tingkat penyerapan panel surya merupakan rasio antara radiasi total yang terserap oleh panel surya terhadap radiasi total yang mengenai permukaan panel surya. Pada kondisi normal, panel surya harus mampu menyerap paling sedikit $90 \%$ dari radiasi matahari yang mengenainya.

Jika panel surya dikendalikan oleh perangkat penjejak titik tegangan maksimum, maka panel akan selalu bekerja pada titik tegangan maksimumnya dan efisiensi sel surya $(n c)$ selalu bernilai sama dengan efisiensi titik tegangan maksimumnya $\left(\eta_{m p}\right)$. Penggunaan perangkat penjejak titik tegangan maksimum ini sangat direkomendasikan untuk meningkatkan kapasitas pembangkitan listrik oleh panel surya. Temperatur sel surya dengan perangkat penjejak titik tegangan maksimum dapat ditentukan sebagai berikut:

$T c=T_{a}+I_{T}\left(\frac{T_{c, N O C T-T a, N D C T}}{T_{e} N D C T}\right)\left(1-\frac{\pi m p}{0,0}\right)$

\section{BAHAN DAN METODE}

Bahan yang digunakan dalam penelitian ini adalah panel surya yang digunakan tipe monokristalin dengan spesifikasi sebagai bertikut :

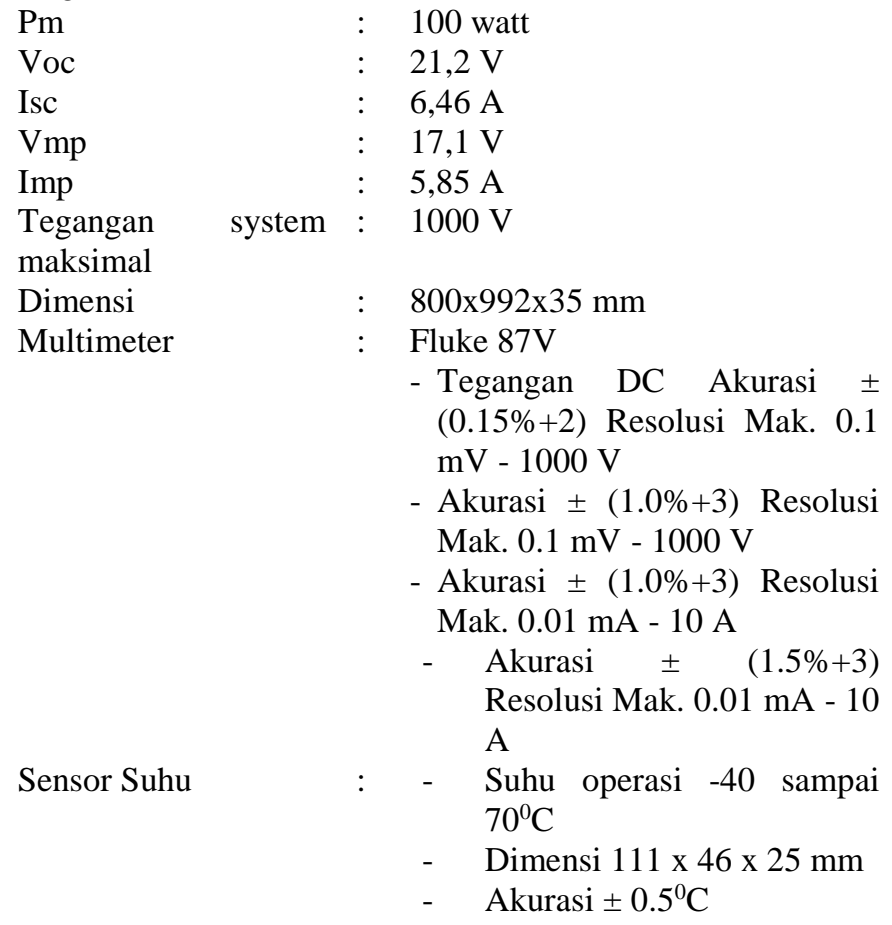

\section{B. Pengambilan Data}

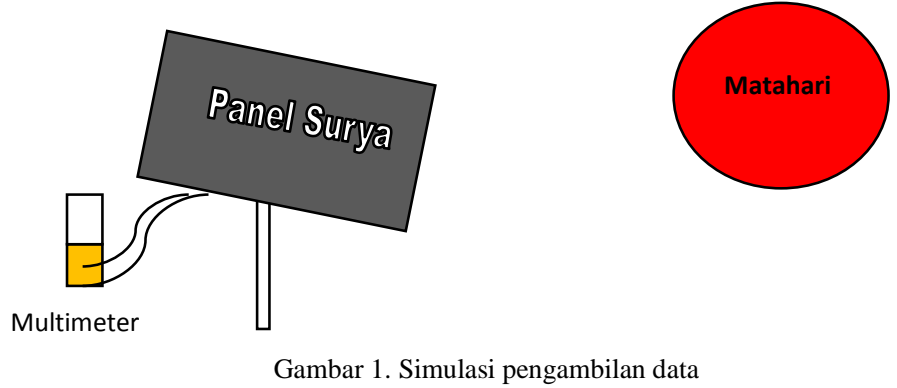

Pengambilan data pada panel surya dilakukan setiap 2 jam dengan menggunakan multimeter untuk mengukur arus dan tegangan yang dihasilkan pada penel surya, dimana output 
dari panel surya berupa tegangan dan arus. Sementara untuk mengukur suhu atau temperature menggunakan sensor suhu.

Berikut adalah cara pengukuran yang dilakukan :

1. Setting pada multimeter dimana probe yang digunakan pengukuran Tegangan DC untuk mengukur VDC pada panel surya dan dilakukan setting ulang pada multimeter dimana probe yang digunakan pengukuran $\mathrm{mA}$ untuk mengukur $\mathrm{mA}$.

2. Pada panel surya terdapat setbox untuk pengukuran output VDC dan mA, maka tempelkan kedua probe multimeter secara bergatian untuk pengambilan data

3. Pada layar display multimeter akan muncul nilai tegangan DC dan arus

Dari hasil pegukuran meliputi tegangan dan temperatur rata-rata wilayah Surabaya (sekitar panel surya) ditunjukkan dalam Tabel 1. Intensitas cahaya matahari rata-rata tinggi terjadi pada bulan September sampai dengan bulan Desember sedangkan pada musim hujan yang terjadi di bulan Januari Maret intensitas matahari menurun dan terendah pada bulan Desember.

TABEL 1. HASIL PENGAMBILAN DATA SUHU DAN TEGANGAN RATA-RATA PANEL SURYA PERIODE BULAN SEPTEMBER 2015 SAMPAI DENGAN APRIL 2016

\begin{tabular}{|c|c|c|c|}
\hline Bulan & Suhu $^{\mathbf{}} \mathbf{C}$ & $\begin{array}{c}\text { Tegangan (DC) } \\
\text { Volt }\end{array}$ & $\begin{array}{c}\text { Arus } \\
\mathbf{~ m A ~}\end{array}$ \\
\hline September & 27.4 & 19.33 & 0.08 \\
\hline Oktober & 28.8 & 19.16 & 0.05 \\
\hline Nopember & 27.16 & 18.96 & 0.05 \\
\hline Desember & 28.5 & 18.7 & 0.06 \\
\hline Januari & 28.8 & 18.15 & 0.06 \\
\hline Pebruari & 28.2 & 18.61 & 0.07 \\
\hline Maret & 29.2 & 18.02 & 0.06 \\
\hline April & 30.1 & 18.78 & 0.06 \\
\hline & & &
\end{tabular}

Data BMKG Surabaya Dalam periode bulan September, temperatur di wilayah Surabaya pada umumnya berkisar dalam rentang $23^{\circ} \mathrm{C}$ sampai $34^{\circ} \mathrm{C}$ dan sangat jarang di bawah $22^{\circ} \mathrm{C}$ atau di atas $35^{\circ} \mathrm{C}$. Pada musim panas/kemarau temperature harian rata-rata tertinggi adalah $33^{\circ} \mathrm{C}$ dan terendah $23^{\circ} \mathrm{C}$.

Pada Gambar 2 menunjukan titik koordinat untuk pengambilan data menggunakan Google Earth versi 7.1.pada posisi $7^{\circ} 18^{\prime} 26.66 \mathrm{~S}$

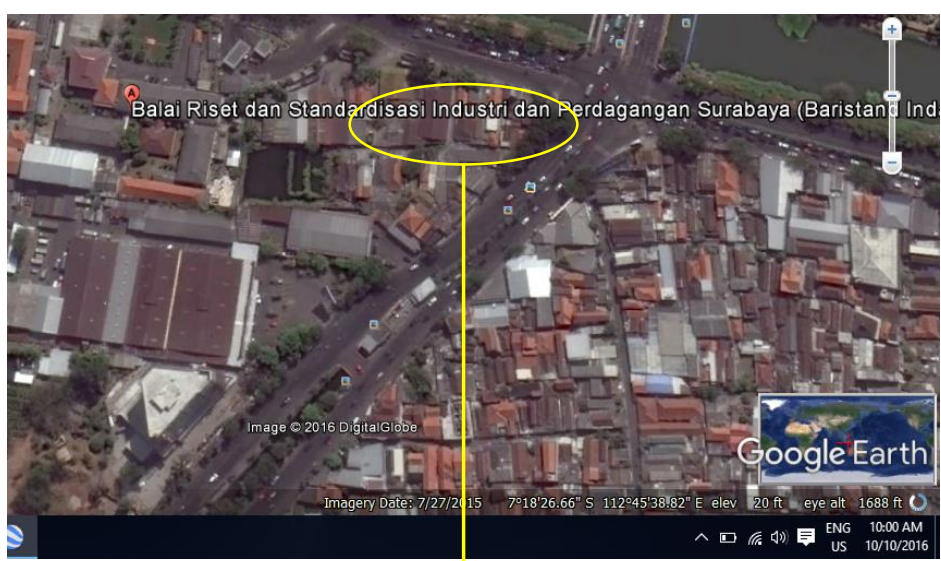

Gambar 2.Titik koordinat pengambilan data

\section{HASIL DAN PEMBAHASAN}

Tabel 1 menunjukkan tegangan listrik rata-rata pada bulan September yang dapat diproduksi oleh panel surya dengan kapasitas maksimum tegangan $21.2 \mathrm{~V}$. Tegangan listrik ratarata tertinggi dihasilkan pada bulan September yaitu sebesar $19.33 \mathrm{~V}$, sedangkan tegangan listrik rata-rata terendah pada bulan Maret, sebesar 18,02 V.

Gambar 3 menunjukkan pengaruh temperature terhadap tegangan listrik rata-rata yang diproduksi oleh panel surya 100W dari jam 08:00 sampai 16:00.[3] Dari kemiringan grafik tegangan suhu, maka dapat ditentukan bahwa terjadi penurunan produksi listrik oleh panel surya sebesar $\left.0.22 \mathrm{~V} /{ }^{0} \mathrm{C}\right)$. Semakin tinggi temperatur lingkungan sekitar panel surya, tegangan listrik yang dihasilkan oleh semakin berkurang.

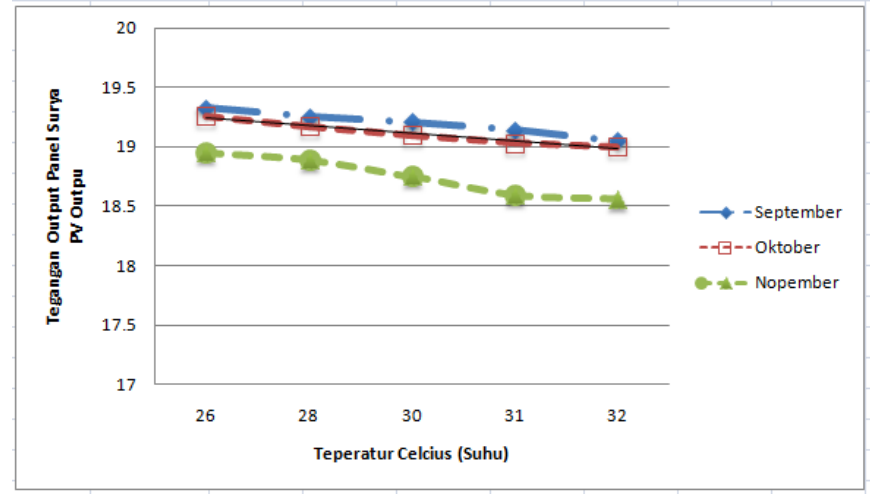

Gambar 3. Pengaruh temperature terhadap tegangan listrik yang dihasilkan panel surya bulan September sampai dengan Nopember 


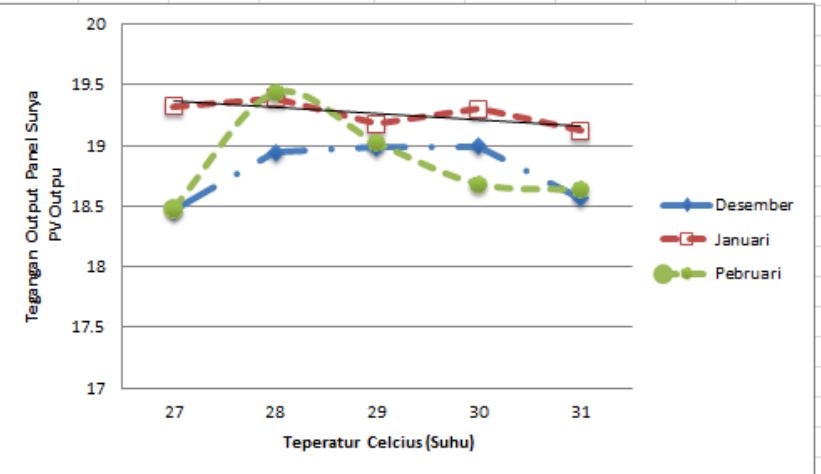

Gambar 4. Pengaruh temperature terhadap tegangan listrik yang dihasilkan panel surya Desember sampai dengan Pebruari

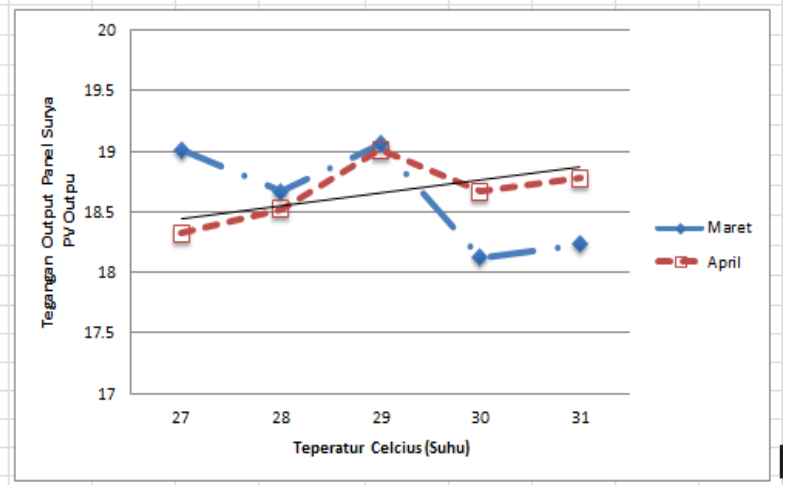

Gambar 5. Pengaruh temperature terhadap tegangan listrik yang dihasilkan panel surya Maret sampai dengan April

\section{KESIMPULAN}

Tegangan listrik yang dihasilkan oleh suatu panel surya tidak hanya tergantung kepada besarnya intensitas radiasi yang diterimanya, namun kenaikan temperature pada permukaan panel surya juga dapat menurunkan besar tegangan listrik tersebut, dimana pada bulan September dengan suhu sekitar $27^{\circ} \mathrm{C}$ tegangan yang dihasilkan $19,33 \mathrm{~V}$. Perubahan temperatur pada panel surya selain disebabkan oleh temperature lingkungan sekitar, juga disebabkan oleh bahan silicon sel-sel surya yang mampu menyerap energi foton sekaligus panas dari radiasi matahari.

\section{UCAPAN TERIMAKASIH}

Penulis mengucapkan terima kasih kepada Ka.Baristand Industri Surabaya yang telah memfasilitasi dalam penelitian dan penulisan KTI

\section{DAFTAR PUSTAKA}

[1] J. Jiang, T. Huang, Y. Hsiao, and C. Chen, "Maximum Power Tracking for Photovoltaic Power Systems," Tamkang J. Sci. Eng., vol. 8, no. 2, pp. $147-153,2005$
[2] D. L. King et al., "Array Performance Characterization and Modeling for Real-Time Performance Analysis of Photovoltaic Systems," 2006 IEEE 4th World Conf. Photovolt. Energy Conf., vol. 2, 2006.

[3] D. L. King, M. A. Quintana, J. A. Kratochvil, D. E. Ellibee, and B. R. Hansen, "Photovoltaic module performance and durability following long-term field exposure," Prog. Photovoltaics Res. Appl., vol. 8, no. 2, pp. 241-256, 2000.

[4] K. H. Khwee, "Pengukuran Kapasitas Daya Panel Surya ( Studi Kasus : Pontianak )," vol. 5, no. 2, pp. 23-26, 2013.

[5] S. Hadji and J. G. Fateh, "Genetic algorithms for maximum power point tracking in photovoltaic systems Keywords," Proc. World Acad. Sci. Eng. Technol., vol. 34, no. October, pp. 1-9, 2011.

[6] I. Houssamo, F. Locment, and M. Sechilariu, "Maximum power tracking for photovoltaic power system: Development and experimental comparison of two algorithms," Renew. Energy, vol. 35, no. 10, pp. 2381-2387, 2010. 